ZOOLOGIA 30 (2): 135-142, April, 2013

http://dx.doi.org/10.1590/S1984-46702013000200003

\title{
History, distribution, and seasonal abundance of the Least Tern Sternula antillarum (Aves: Charadriiformes: Sternidae) in Brazil
}

\author{
Caio J. Carlos ${ }^{1,3} \&$ Carmem E. Fedrizzi²
}

\author{
${ }^{1}$ Laboratório de Sistemática e Ecologia de Aves Mamíferos Marinhos, Departamento de Zoologia, Universidade Federal do \\ Rio Grande do Sul. Avenida Bento Gonçalves 9500, Agronomina, 91501-970 Porto Alegre, RS, Brazil. \\ 2 Departamento de Zoologia, Universidade Federal do Rio Grande do Sul. Avenida Bento Gonçalves 9500, Agronomina, \\ 91501-970 Porto Alegre, RS, Brazil. \\ ${ }^{3}$ Correspondence author. E-mail: macronectes1@yahoo.co.uk
}

\begin{abstract}
We review existing data on the distribution of the Least Tern, Sternula antillarum along the Brazilian coast, based on the literature and museum specimens, and present results of a year-long study (October 2008 to September 2009) on the seasonal abundance of this species on a large tidal flat area, Cajuais Bank, in the State of Ceará, northeastern Brazil. We evaluate whether the observed variation in the abundance of terns is due to the occurrence of an undocumented breeding colony, or alternatively, whether it results from an influx of migrants from the Northern Hemisphere. The recovery of historical data revealed that all literature references on the distribution of birds in the Americas, published up to the late 1990s include Brazil in the non-breeding range of the Least Tern. This inclusion is based on a few, old (late $19^{\text {th }}$ and early $20^{\text {th }}$ centuries) museum specimens, all of which have been collected on the northern and north-eastern coasts of this country'. From the late 1980s, birds continued to be occasionally recorded along the coastline, running from the State of Amapá $\left(01^{\circ} \mathrm{N}\right)$ up to the State of Bahia $\left(10^{\circ} \mathrm{S}\right)$, with records of single individuals in south-eastern and southern Brazil. An alleged record from Rocas Atoll, $260 \mathrm{~km}$ off the Brazilian mainland, might tentatively refer to the Old World Little Tern S. albifrons. At Cajuais Bank, Least Terns occurred from October 2008 to April 2009 , and in September 2009. The highest numbers ( $>800$ individuals) were recorded in January-February (Southern Hemisphere's summer). The species was observed in rather small numbers $(<30)$ in March-April (early-mid Southern Hemisphere fall) and in September (early Southern Hemisphere spring), being absent from the area in May-August (Southern Hemisphere's fall and winter). In October-December 2008 (Southern Hemisphere's spring), and September 2009 (early Southern Hemisphere's summer), no birds were in breeding plumage. In January, about 32\% of the birds were in breeding plumage, while from February-April (Southern Hemisphere's summer to mid fall) all were in breeding plumage. This pattern is consistent with what would be expected for migratory birds. The Cajuais Bank itself (and adjacent beaches and inland environments) holds the largest numbers of Least Terns recorded in Brazil, thus being one of the most significant sites along the migratory route of the species.
\end{abstract}

KEY WORDS. Coastal habitats; Nearctic-Neotropical migration; seabirds.

The Least Tern, Sternula antillarum Lesson, 1847, is a small seabird (total length: $210-230 \mathrm{~mm}$; body mass: $30-45 \mathrm{~g}$ ) that breeds along the southern coasts and major interior rivers of the USA, coasts of Mexico, the Caribbean and the islands off northern South America. It is closely related to, and was once considered to be a subspecies of, the Old World Little Tern Sternula albifrons (Pallas, 1764), from which it can be distinguished by plumage and vocal characters (MASsEy 1976, AOU 1983, Gochfeldl \& Burger 1996, Thompson et al. 1997). The Least Tern was formerly placed in Sterna Linnaeus, 1758, but a phylogenetic analysis of terns using mitochondrial DNA sequences revealed that this genus, as traditionally conceived, was paraphyletic (BRIDGE et al. 2005). A proposed reclassification resurrected Sternula Boie, 1822, for all 'small-sized white terns', including the Least Tern, restricting Sterna to the 'large-sized white terns' (BRIDGE et al. 2005).

Five subspecies of the Least Tern have been described from the Americas, the validity of which is the source of much debate. In recent years, only three races are often recognized: The nominate antillarum (Eastern or Coastal Least Tern) of the Atlantic coast of the USA, eastern Mexico, Bermuda, the Caribbean, and islands off Venezuela; S. antillarum browni (Mearns, 1916) (California Least Tern) of the Pacific coast of North America, from central California south to western Mexico; and S. antillarum athalassos (Burleigh \& Lowery, 1942) (Interior Least Tern) of the inland USA, primarily the Mississippi River and its 
tributaries. Eastern Least Terns from the USA and Interior Least Terns leave their breeding grounds in the late northern summer-early fall to spend the non-breeding months along the coasts of northern South America, including Brazil (GochFelD \& Burger 1996, Thompson et al. 1997, Johnson et al. 1998, Draheim et al. 2010).

Until recently, the Least Tern was regarded as an exclusively Nearctic migrant to Brazil because birds with North American bands were recovered in this country and no breeding colony was ever discovered (PINTO 1938, 1964, 1978, SICK 1985 , 1997, Olmos 2002). However, a colony of 60-70 pairs was found breeding on an estuarine island in the State of Maranhão, northern Brazil, during May-July 2008 (RodRIgues et al. 2010). This information promptly led to changing the status of the Least Tern in the most recent check-list of Brazilian birds, from 'visitor' to 'resident' species (CBRO 2010).

Although the Least Tern has been well-studied on its breeding grounds in the USA (see GochFeld \& BURGER 1996, Thompson et al. 1997), little information other than distribution records is available for this species in Brazil. In this paper we review existing data on the distribution of Least Terns along the Brazilian coast. We also present the results of a year-long study of the seasonal abundance of Least Terns on a large tidal flat area, Cajuais Bank, north-eastern Brazil. We were particularly interested in evaluating whether the observed variation in the abundance of terns was consistent with the occurrence of a breeding colony nearby, or whether it resulted from movements of migrants from the Northern Hemisphere.

\section{MATERIAL AND METHODS}

We compiled information on the distribution and abundance of the Least Tern in Brazil from the literature, specimens deposited in collections in Brazil and abroad, and our own fieldwork. Information on relevant specimens (i.e., high resolution photographs, measurements, labels data etc.) at the Naturhistorisches Museum Wien, Austria, and the Field Museum of Natural History, Chicago, USA, was made available to us by the curatorial staff (see Acknowledgments). We also examined a specimen at the Universidade Federal de Pernambuco, Recife, Brazil (CARlos et al. 2005).

During a one year-period, from October 2008 to September 2009, a daily count during three consecutive days per month was carried out at Cajuais Bank $\left(04^{\circ} 41^{\prime} \mathrm{S}, 37^{\circ} 21^{\prime} \mathrm{W}\right)$ in eastern Ceará. The area is the largest intertidal platform of this State. Low tide exposes huge mud flats (up to $2 \mathrm{~km}$ seaward), thus providing a vast roosting/forage area for sea- and shorebirds. The site is located on the semi-arid part of the north-eastern coast of Brazil, a region characterized by an irregular and unpredictable rainy season (usually February-May) and very dry conditions during the second half of the year (CAmpos et al. 2003). Only one count was performed at the study area in April 2009 because heavy rains made access to the site difficult and dangerous.
Because the coastal zone of Ceará is flat, river mouths form extensive estuaries, but due to the limited rainfall regime, these estuaries are hypersaline during most of the year. Low riverine freshwater discharge results in relatively low-nutrient coastal waters, but stable, high temperatures (average is $28^{\circ} \mathrm{C}$ year-round), together with diverse habitats along the extensive and shallow shelf (e.g., seagrass beds, coral reefs, mangroves etc.) create an environment with high species diversity (CAmpos et al. 2003).

Fieldwork was always carried out in good weather conditions, on foot, and during a diurnal low tide. Terns concentrate at the outer edge of the tidal flat at low tides, being easily counted with binoculars ( $7 \times 45 \mathrm{~mm}$ ) and spotting scopes (20$60 \times 160 \mathrm{~mm}$ ). As the tide comes in, the birds leave the area (pers. obs.), probably to roost in adjacent inland habitats and/ or to forage in nearby waters. To assess seasonal patterns in the abundance of Least Terns at Cajuais Bank, we defined the Southern Hemisphere seasons as spring (September-November), summer (December-February), fall (March-May), and winter (June-August).

While in non-breeding areas, migratory Least Terns may be confused with the morphologically-similar Yellow-billed Tern Sternula superciliaris (Vieillot, 1819), which occurs mainly along large rivers east of the Andes in South America, but often wanders to seacoasts during the non-breeding season. Although a primarily fresh-water species, the Yellow-billed Tern has been reported to nest on coastal habitats of north-eastern and southern Brazil (Sick 1997, CARLos 2009). As Yellow-billed Terns have been reported from eastern Ceará (GIRÃo et al. 2008), we were especially careful while counting the birds, to avoid misidentifications.

Juveniles, immature and non-breeding adults of Least and Yellow-billed Terns exhibit a rather similar plumage pattern, but the Least Tern has a dark-colored bill, whereas the Yellowbilled has a mostly yellow bill with a dark tip and an obvious dark patch around the nostrils. Breeding individuals of both species have only slight plumage differences, of which the amount of black on the wing-tip appears to be a good, although not infallible, criterion to separate them. In the Least Tern the two (rarely three) outermost primaries are dark, compared with three (rarely two-four) in the Yellow-billed. In the Least Terns, the bill is yellow with a dark tip in the breeding season, but in some individuals it is entirely yellow. Breeding Yellow-billed Terns always have completely yellow bills (MAssey \& ATwooD 1978, Thompson et al. 1997, Hayes 2001).

At least during one of the three monthly counts, we differentiated terns between breeding and non-breeding individuals, based on the criteria cited above, and the following head plumage-pattern, after Massey \& Aтwood (1978) and THомpson et al. (1997). Non-breeding birds exhibit a white forehead, lores, and crown with variable black flecking. Breeding birds have a black cap and nape with a well-defined white forehead area extending backward on the sides of the crown to above the 
eye; the black of the crown extends forward through the eye and lores to the base of the upper mandible.

\section{RESULTS}

\section{Review of Records and Abundance}

The Swiss-Brazilian naturalist Emil A. Goeldi, in his 'Álbum de aves da Amazônia' (Goeldi 1904: pl. 1, fig. 8), provided an illustration of a breeding-plumaged Least Tern, but offered no further details. This appears to be the first indication of the species occurrence in Brazil. Ten years later, the German-born Brazilian ornithologist EmiLIE SNETHLAGE (1914) not only cited the work of Goeldi, but also listed three specimens in the collections of the Museu Goeldi of Belém, two males and one unsexed individual, all from Ilha dos Machados (= Ilha Machadinho), a small island $9 \mathrm{~km}$ off the northern side of Marajó Island in the State of Pará (Fig. 1). E. Snethlage (1914) provided no further details as to the name of the collector of the specimen, collection number, date of collection, or age/ plumage type, but these were still preserved in the Museu Goeldi, at least up to the late 1900s, as it can be inferred from the work of Henriques \& Oren (1997) on the birds of Marajó.
The ornithologist Othmar Reiser, who in 1903 participated in an Austrian expedition to north-eastern Brazil, recorded the Least Tern while on the coast of the State of Piauí (ReIser 1905, 1910). He and the taxidermist Johan Santarius collected five birds in sand dunes near Amarração (currently Luís Correia; Fig. 1), all of which are still extant in the Naturhistorisches Museum Wien (E. Bauernfeind in litt. 2010). Three birds were taken on September 14, two of which (NMW 38,726 and 38,727) are nonbreeding males with black bills, while the other (NMW 38,728) is a juvenile with mottled pale-brown feathering on the back and upper-wings, and a dark carpal bar on the leading inner edge of the wing. The next day, a male (NMW 38,730) and a female (NMW 70,522), both in breeding plumage, were collected. Probably due to its wholly yellow bill, male NMW 38,730 has subsequently been considered to be a Yellow-billed Tern, and the name on the original label has been changed accordingly (judging from the handwriting by Reiser himself; E. Bauernfeind in litt. 2010). However, based on examination of the coloration of outermost primaries, we are of the opinion that Reiser's original identification was correct.

In July 1923, the German ethnographer Emil-Heinrich Snethlage, in association with his aunt, Emilie, conducted an

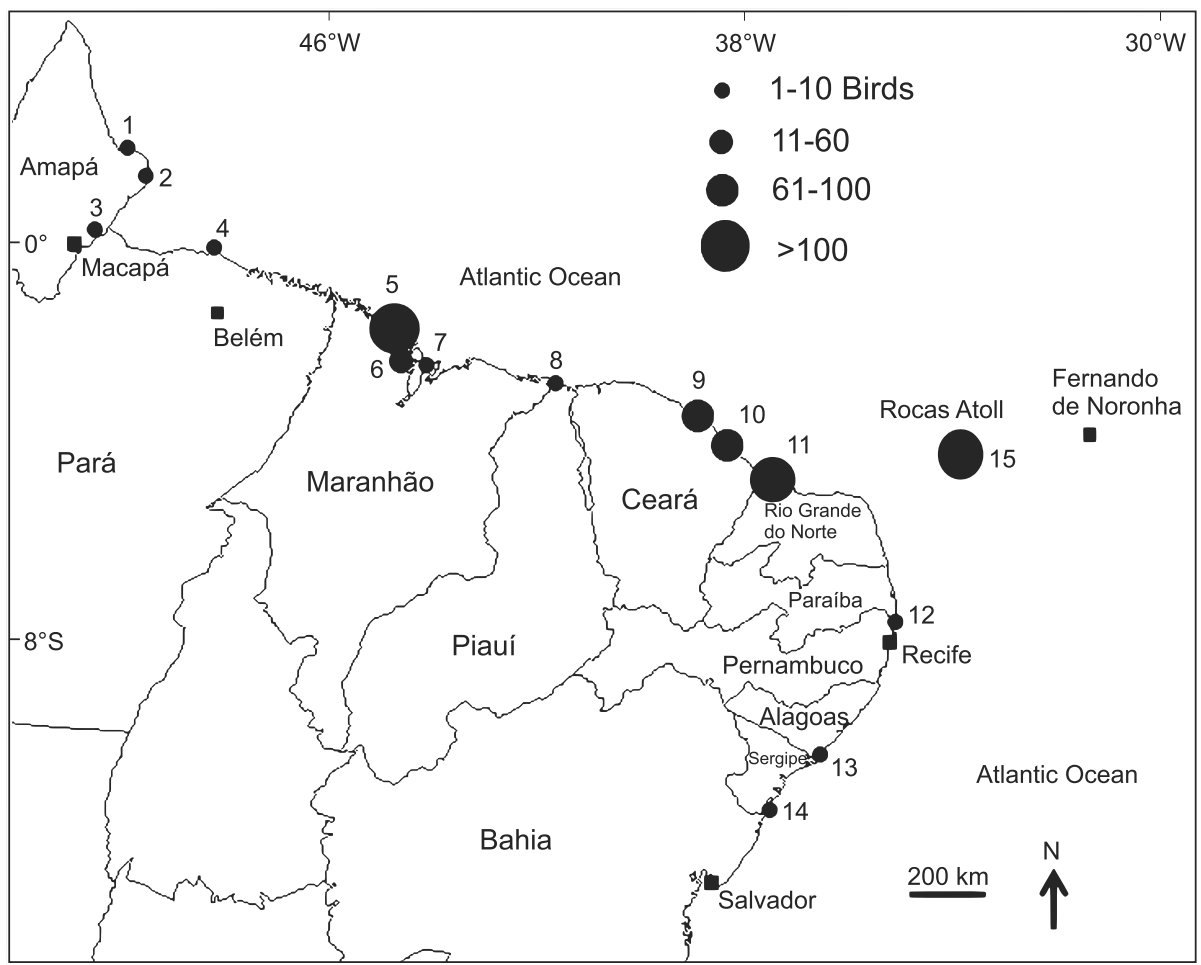

Figure 1. North and northeast Brazil, showing localities where the Least Tern Sternula antillarum was reported and its abundance. 1) Estação Ecológica Maracá-Jipioca, 2) Reserva Biológica do Lago Piratuba, 3) Área de Proteção Ambiental do Curiaú, 4) Ilha dos Machados, 5) Cururupu, 6) Ilha Curupu (breeding site), 7) São Luís, 8) Amarração (= Luís Correia), 9) São Gonçalo do Amarante/Fortaleza, 10) Cascavel, 11) Icapuí/Cajuais, 12) Coroa do Avião, 13) Área de Proteção Ambiental de Piaçambuçu, 14) Mangue Seco, and 15) Rocas Atoll. 
ornithological expedition through the northeast of Brazil. After his aunt returned to Belém, Emil travelled alone between March 1924 and April 1925 (E.-H. Snethlage 1928a, b). This two and a half year expedition, most of which spent in Maranhão, resulted in the collection of about 2,000 bird-skins, all eventually deposited at The Field Museum of Natural History (Hellmayr 1929). On 21 July 1923, two specimens of the Least Tern were obtained from coastal swamps near São Luis (Fig. 1), of which FMNH 64,083 is a non-breeding female, while FMNH 64,084 is a female in breeding plumage and wholly yellow bill. HeLLMAYR (1929), who studied the material collected by E.-H. Snethlage initially thought these specimens were Yellow-billed Terns, but later changed his identification (Hellmayr \& Conover 1948).

Subsequent authors (e.g., Murphy 1936, PinTo 1938, 1964, 1978, Hellmayr \& Conover 1948, Sick 1985) either directly or indirectly included Brazil within the Least Tern's non-breeding range, almost exclusively on the basis of the above-cited specimens. This inference is based on the fact that no published record of this tern in the country appeared until the second half of the 1980s, when TeIXeIRA et al. (1986) reported an undated specimen (MNRJ 18,846) in the Museu Nacional, Rio de Janeiro, collected in Angra dos Reis $\left(23^{\circ} 00^{\prime} \mathrm{S}, 44^{\circ} 18^{\circ} \mathrm{W}\right)$, State of Rio de Janeiro, a place situated more than 2,000 km away from the nearest locality known for the species at that time (i.e., Amarração in Piauí). However, this specimen, collected by parasitologists Olympio. O.R. da Fonseca and Lauro P. Travassos, went long overlooked. Late in 1940, the German ornithologist Adolf Schneider, who headed an expedition of the Berlin Museum of Natural History to Brazil in 1929-40, was asked by João Moojen de Oliveira, then the head curator of the vertebrate section of the Museu Nacional, to reorganize the bird collection of that institution (PACHeCo \& BAUER 1995). According to J.F. Pacheco (in litt. 2011), the existing specimens up to that date received collection numbers between 1 and 19,200 . Thus it can be concluded that the above-mentioned specimen from Angra dos Reis had actually been collected sometime before December 1940.

From the late 1980s to the present, singles or small groups of Least Terns continued to be occasionally recorded, mainly in September-October, along the coastline from the State of Amapá up to the State of Bahia (Hays et al. 1999, Carlos et al. 2005, Cabral et al. 2006, Aguiar \& Naiff 2010, Aguiar et al. 2010, Xavier \& Boss 2011); the exceptions being Rodrigues (2007) and GIRÃo et al. (2008), who respectively reported flocks of about 100 birds in Maranhão and Ceará, and our data from Cajuais Bank (Fig. 1). However, in Brazil, the species has been recorded as far south as $30^{\circ} \mathrm{S}$ in the State of Rio Grande do Sul (Aldabe et al. 2010, SANABria \& Brusco 2011). It is worth mentioning that the Least Tern is also known from a single record each in Uruguay (Rocchi 2011) and Argentina (OlRog 1969).

In addition to the historical specimens, the only additional Least Tern collected in Brazil is a juvenile mist-netted at Coroa do Avião in the State of Pernambuco, on 23 October
2003 (now in the collection of the Universidade Federal de Pernambuco - UFPE 3,986; Carlos et al. 2005). Also noteworthy is that Olmos (2002) reported two specimens banded in the USA and recaptured on the southern coast of the State of Alagoas, on January 10, 1992.

An exceptional record from the Rocas Atoll, located 260 $\mathrm{km}$ northeast off the State of Rio Grande do Norte and $145 \mathrm{~km}$ west of Fernando de Noronha Archipelago (AzEvEDo-JúNIOR 1992) deserves a detailed comment. Azevedo-Júnior (1992) identified up to 200 small white terns he saw on Rocas Atoll in March 1990 as 'S. albifrons', probably because at that time all Brazilian bird specialists still considered the Least Tern as a subspecies of the Little Tern (PINTo 1938, 1964, 1978, Sick 1985). Only SICK (1997) regarded the Least Tern as a separate species. This induced Vooren \& BRusque (1999) to re-interpret the record from Rocas Atoll as an occurrence of the Least Tern, also leading the Comitê Brasileiro de Registros Ornitológicos to move Little Tern to the 'Tertiary list of Brazilian birds' (i.e., the one including species 'with specific record published for the country, but with invalid documental evidence or with unlikely occurrence in Brazil and lacking documental evidence').

Rocas Atoll, along with the Archipelagos of Fernando de Noronha and São Pedro e São Paulo, is found exactly within the convergence zone of the two trade-winds systems. Northeast trade winds blow from subtropical latitudes $\left(\mathrm{ca} .30^{\circ} \mathrm{N}\right)$ along the eastern North Atlantic, towards the north-east coast of South America and the Caribbean. South-east trade winds blow from about $30^{\circ} \mathrm{S}$, along the coast of Africa, and then across the Atlantic to the tropical South American coast (TomczAcK \& Godfrey 2003). The prevailing westerly winds in the region are believed to assist the displacement of birds from Africa and Europe to the Americas, explaining their occurrence in the Brazilian oceanic islands (e.g., BENCKe et al. 2005, Fedrizzi et al. 2007). Therefore, the small terns from Rocas Atoll might tentatively refer to the Old World Little Tern rather than to the Least Tern, although in the lack of tangible evidence, the true identity of these birds is only a matter of speculation.

\section{Seasonal abundance at Cajuais Bank}

Least Terns occurred at Cajuais Bank from October 2008 to April 2009, and in September 2009. The highest numbers (>800 individuals) were recorded during January and February (southern summer; Fig. 2). The species was observed in rather small numbers $(<30)$ in March and April (southern early to mid-fall) and in September (early spring), being absent from the area from May to August (southern late fall and winter; Fig. 2).

From October to December 2008, and in September 2009 (southern spring and early summer), no bird was seen in breeding plumage (Fig. 3). In January 2009, approximately 32\% of the birds were in breeding plumage and with dark tip to yellow bills, while from February to April (southern summer to middle fall) $100 \%$ of birds were in breeding plumage (Fig. 3). In addition, not a single juvenile Least Tern has been observed in the area. 


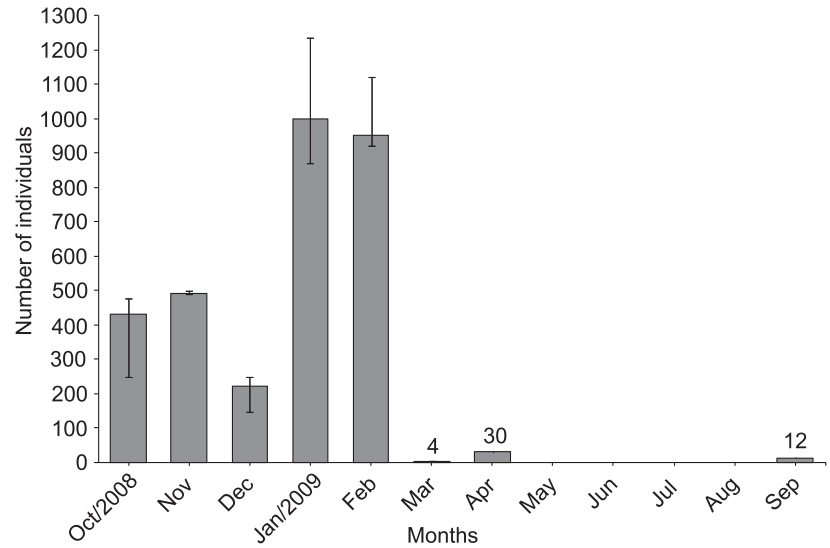

Figure 2. Monthly variation in the abundance (data are: median, maximum and minimum) of Least Terns Sternula antillarum at Cajuais Bank, State of Ceará, northeast Brazil.

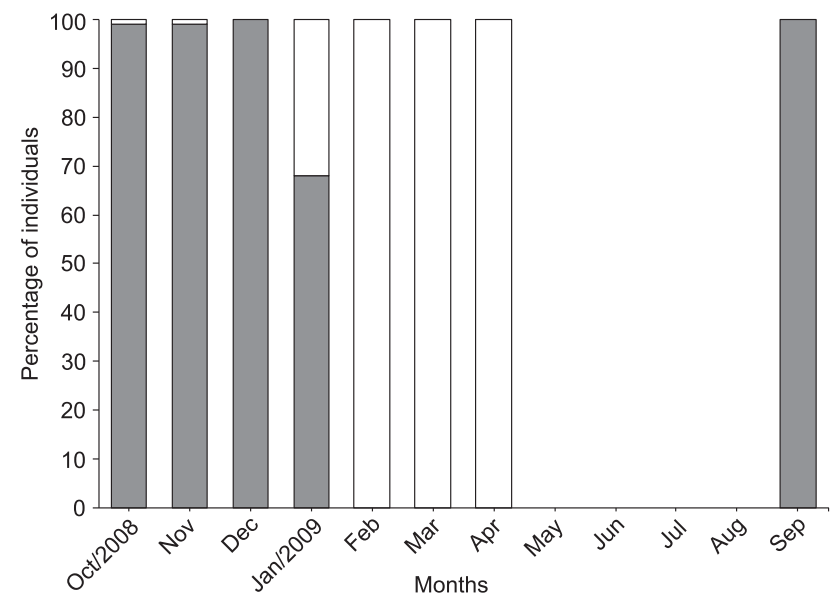

Figure 3. Monthly percentage (counts) of Least Terns Sternula antillarum at Cajuais Bank, State of Ceará, northeast Brazil, exhibiting breeding (white) and non-breeding (grey) plumages.

\section{DISCUSSION}

Reference works on the distribution of birds in the Americas published up to the late 1990s (e.g., Murphy 1936, Hellmayr \& Conover 1948, Sick, 1985, 1997) all included Brazil in the non-breeding range of the Least Tern. Supporting data were based on a few, old museum specimens. Indeed, much of the knowledge of seabirds from the northern/north-eastern coast of Brazil, roughly between $01^{\circ} \mathrm{N}-05^{\circ} \mathrm{S}$, up to the early $2000 \mathrm{~s}$ are derived from specimens collected in the late 19th and early 20th century (e.g., Lima et al. 2010), a period that corresponds to the so-called 'foreigner expeditions' (from 1500 to mid19 th century), and 'natural history museums' (from mid-19th century to the 1970s) phases of Brazilian ornithology (Alves et al. 2008). Brazilian ornithologists interested in seabirds are mainly resident in southern Brazil, this explaining the relative lack of studies in northern and north-eastern Brazil (ANtas 1991, Moraes-Ornellas 2009). Only very recently has this situation begun to change. For instance, another seabird long regarded to be a Nearctic migrant to the coast of northern Brazil, the Laughing Gull Leucophaeus atricilla (Linnaeus, 1758), was until the late 1990s known in the country almost exclusively from twelve old specimens (e.g., Novaes 1974, Henriques \& Oren 1997, Oren 1991). It was only after recent fieldwork that ornithologists estimate that $\sim 30,000$ spend part of the non-breeding season on the northern Brazilian coast (Lima et al. 2010).

From the literature and data presented in this study, it may be concluded that the coasts of Maranhão and Ceará are the most important areas of Brazil for Least Terns. In the former State, Curupu Island in the municipality of Raposa is the only known breeding site for the species in the country (RoDRIGUES et al. 2010). Moreover, flocks with up to 170 birds were observed roosting on sandy beaches in the municipality of Cururupu (Rodrigues 2007). In Ceará, Cajuais Bank harbours by far the largest numbers of Least Terns $(>1,000)$ recorded in Brazil. Here, and in the neighbouring States of Piauí and Rio Grande do Norte, suitable roosting and breeding habitats (i.e., sandy beaches, sandbars, tidal flats, lagoons and associated swamps etc.) exist for the species, but this region has never been systematically surveyed for seabirds. Grey-headed Gulls Chroicocephalus cirrocephalus (Vieillot, 1818), Yellow-billed Terns, and Gull-billed Terns Gelochelidon nilotica (Gmelin, 1789) are reported to breed on salt pans on the coast of Rio Grande do Norte (CARLOS 2009). Mangroves and salt-works are a conspicuous feature of Piauí, Ceará and Rio Grande do Norte. The shallow tanks support a large biomass of brine shrimps Artemia sp., which serves as food for waterbirds, while sandbanks amidst the ponds provide nesting and roosting sites (CARLOS 2009). Large concentrations of Least Terns, and as yet to be discovered breeding sites, are likely to occur in coastal areas of Ceará other than Cajuais Bank, Rio Grande Norte and Piauí, but more fieldwork is needed to confirm this hypothesis.

Given that birds banded in the USA have been recovered in the Brazilian Northeast (Olmos 2002), one can assume that migrant Least Terns mix with residents along the country's northern coast. Most historical and recent Brazilian records of Least Terns were from the southern spring (September-October) and summer (December-January), not including observation of the species breeding in Maranhão (RoDRIGUEs et al. 2010). Although these data suggest some pattern of seasonality, they should be treated with care. Remsen (2001) summarized the limitations (e.g., low sample effort, accessibility of study areas, bias towards the field seasons etc.) of determining the seasonal distribution of migratory species. Our analysis of data from Cajuais Bank presented in this study is the first attempt to assess the seasonal abundance of Least Terns in Brazil. 
In the USA, the Least Tern usually breeds from mid April to July, after which it migrates to wintering (contra-nuptial) areas in the Caribbean and northern South America (Gochfeld \& Burger 1996, Thomson et al. 1997). At Cajuais Bank, the species was present from September-April (southern spring to early-fall), but absent during May-August (southern late-fall to late-winter). Highest numbers were observed in January-February, while lower numbers were observed in March-April, and in September. Birds arrive at Cajuais bank in the spring, are very abundant there all through the summer, and leave the area from early-fall onwards. This pattern seems to be consistent with what would be expected for migratory birds. In Suriname, the nearest place for which published data on seasonal numbers of Least Terns are available, SpaAns (1978) recorded the species in all months but December, with highest numbers in May (southern late-fall) and in August-September (southern late-winter and early-spring). Differences in peak abundance of Least Terns between Cajuais Bank and the Surinam coast suggests that birds spending the non-breeding season in north-eastern Brazil pass through the Guiana's coast while en route to and from their breeding grounds.

Observation of seasonal plumage types (i.e., breeding or non-breeding) also supports the hypothesis that Least Terns at Cajuais Bank are migrants from elsewhere. In this species, moult to non-breeding plumage begins during the breeding season, and is completed while birds are on their non-breeding grounds. Moult to breeding plumage generally commences in February (Thompson et al. 1997). In the spring, almost all terns at Cajuais Bank were already in non-breeding plumage, and with black bills. Most likely, they will have completed this moult somewhere along northern Brazil before arriving in Ceará. By February, just before most terns leave Cajuais Bank, they were all in full-breeding plumage and with dark tipped to yellow bills, thus apparently moulting a little earlier than reported in the literature (THOMPSON et al. 1997).

In Maranhão, Least Terns were found breeding in MayJuly (Rodrigues et al. 2010), curiously the same breeding period of their North American counterparts. Birds at Cajuais Bank, however, are unlikely to be part of a local-breeding population, because during the winter they were absent, not only from tidal flats, but also from adjacent beaches and inland habitats (e.g., salt works, salt flats, mangroves, lagoons, etc.). In contrast, some individuals of other migratory species, such as the Semipalmated Plover Charadrius semipalmatus Bonaparte, 1825, and the Common Tern, remained in the area during the winter (unpublished data); these were presumably immature birds that had hatched in the previous year. No data on dispersal of the Brazilian-breeding birds are available to date (RodRIGues et al. 2010), but due to the abundance of safe, roosting and foraging habitats near their colony, it is unlikely they wander very far.

The United States Fish and Wildlife Service does not recognize any subspecies of Least Tern. The agency considers instead the three populations as distinct geographic units, of which the California and Interior populations are listed as federally endangered because of population declines related to habitat loss (USFWS 1985, 1990). Assuming that the birds at Cajuais Bank are North American migrants, they could be either from the non-federally listed Eastern population or from the Interior population. The assignment of Least Tern individuals to any population (or subspecies) on the basis of morphology is very difficult, due to lack of clear differences among populations ( $\mathrm{TH}-$ ompson et al. 1997, Draheim et al. 2010, but see Johnson et al. 1998). The two USA birds recaptured in Brazil were banded in Florida and near Boston, respectively (Olmos 2002), indicating that they belonged to the Eastern population. However, the occurrence of the Interior Least Tern in Brazil cannot be ruled out, because Gochfeld \& Burger (1996) and Thompson et al. (1997) indicate that Brazil is within the non-breeding range for this population, although they do not cite explicit evidence.

Regardless of the subspecific identity of Least Terns, Cajuais Bank (and adjacent beaches and inland environments) holds the largest numbers of the species recorded in Brazil, thus being one of the most significant sites along the migratory route of the species. The area is the largest tidal plain in Ceará, and is probably the most important stopover site for migratory birds in the State, and among the most important in the country. This assumption is further corroborated by the recent discovery of significant flocks (> 500 individuals) of Red Knots Calidris canutus rufa (Wilson, 1813) (unpublished data) using this area, as well as its importance to Least Terns.

A partnership was established between local non-governmental organizations, Universities, and four coastal municipalities to produce a preliminary assessment, and on February 2009 a formal request was filed with the Brazilian Ministry of Environment to promote the creation of a large Marine Protected Area that would encompass critical coastal habitats as the Cajuais tidal plain and its associated mangroves.

\section{ACKNOWLEDGMENTS}

Our studies were supported by the United States Fish and Wildlife Service (Neotropical Migratory Conservation Act) through a grant to Associação de Pesquisa e Conservação de Ecossistemas Aquáticos. CJC is currently supported by the Coordenação de Aperfeiçoamento de Pessoal de Nível Superior, Brazil. E. Bauernfeind (NMW) and D. Willard (FMNH) provided us with all information and photographs of the specimens under their care. J.F. Pacheco kindly sent us information on the MNRJ specimen. The manuscript benefited from reviews and comments made by Michael Amaral (USFWS) and Arne J. Lesterhuis (BirdLife International), three anonymous referees and editorial advice of Diego Astua.

\section{LITERATURE CITED}

Aguiar, K.M.O \& R.H. Naiff. 2010. Composição da avifauna da Área de Proteção Ambiental do Rio Curiaú, Macapá, Amapá, Brasil. Ornithologia 4 (1): 36-48. 
Aguiar, K.M.O; R.H. Naiff \& B. Xavier. 2010. Aves da Reserva Biológica do Lago Piratuba, Amapá, Brasil. Ornithologia 4 (1): 1-14.

Aldabe, J.; A. Rocchi \& G. Mondón. 2010. Primer registro de Sternula antillarum Lesson, 1847 (Aves, Charadriiformes) para el estado de Rio Grande do Sul, Brasil. Atualidades Ornitológicas 158: 4-5.

Alves, M.A.S.; J.M.C. Silva \& E.S. Costa. 2008. Brazilian ornithology: history and current trends. Ornitología Neotropical 19 (Suppl.): 391-399.

ANTAS, P.T.Z. 1991. Status and conservation of seabirds breeding in Brazilian waters, p. 141-158. In: J.P. Croxall (Ed.). Seabird status and conservation: a supplement. Cambridge, International Council for Bird Preservation, Technical Publication \#11, 314p.

AOU (American Ornithologists' Union). 1983. Check-list of North American birds. Washington, D.C., American Ornithologists' Union, $6^{\text {th }}$ ed., XXIV+877p.

Azevedo-Júnior, S.M. 1992. Observação de aves oceânicas e limícolas na Reserva Biológica Marinha do Atol das Rocas. Cadernos Ômega da Universidade Federal Rural de Pernambuco, Série Ciências Aquáticas 3: 49-58.

Bencke, G.A.; P. Ott; I. Moreno; M. Tavares \& G. Caon. 2005. Old World birds new to the Brazilian territory in the Archipelago of São Pedro and São Paulo, equatorial Atlantic Ocean. Ararajuba 13 (1): 126-129.

Bridge, E.S.; A.W. Jones \& A.J. Baker. 2005. A phylogenetic framework for the terns (Sternini) inferred from mtDNA sequences: implications for taxonomy and plumage evolution. Molecular Phylogenetics and Evolution 35 (2): 459-469. doi:10.1016/j.ympev.2004.12.010

CabraL, S.A.S.; S.M. AZEvedo-JúnIOR \& M.E. LaRAZZÁbal. 2006. Levantamento das aves da Área de Proteção Ambiental de Piaçabuçu, no litoral de Alagoas, Brasil. Ornithologia 1 (2): 161-167.

Campos, A.A.; A.Q. Monteiro; C. Monteiro-Neto \& M. Polette. 2003. A zona costeira do Ceará: diagnóstico para a gestão integrada. Fortaleza, Associação de Pesquisa e Preservação de Ecossistemas Aquáticos, 292p.

Carlos, C.J. 2009. Seabird diversity in Brazil: A review. Sea Swallow 58: 17-46.

Carlos, C.J.; C.E. Fedrizzi \& S.M. Azevedo-Júnior. 2005. Notes on some seabirds of Pernambuco State, Brazil. Bulletin of the British Ornithologists' Club 125 (2): 140-147.

CBRO (Comitê Brasileiro de Registros Ornitológicos). 2010. Lista das aves do Brasil. Nona Edição. Available online at: http://www.cbro.org.br [Accessed: 24.VII.2012].

Draheim, H.M.; M.P. Miller; P. Baird \& S. Haig. 2010. Subspecific status and population genetic structure of Least Terns (Sternula antillarum) inferred by mitochondrial DNA controlregion sequences and microsatellite DNA. The Auk 127 (4): 807-819. doi:http://dx.doi.org/10.1525/auk.2010.09222

Fedrizzi, C.E.; C.J. Carlos; T. Vaske-Jr; L. Bugoni; D. Viana \& D.P. Véras. 2007. Western Reef-Heron Egretta gularis in Brazil
(Ciconiiformes: Ardeidae). Revista Brasileira de Ornitologia 15 (3): 581-483.

Girão, W.; C. Albano; A.A. Campos; T. Pinto \& C.J. Carlos. 2008. Registros documentados de cinco novos trinta-réis (Charadriiformes: Sternidae) no estado do Ceará, nordeste do Brasil. Revista Brasisleira de Ornitologia 16 (3): 252-255.

Gochfeld, M. \& J. Burger. 1996. Family Sternidae (terns), p.572623. In: J. del Hoyo; A. Elliott \& J. Sargatal (Eds.). Handbook of the birds of the World. Barcelona, Lynx Edicions, vol. 3, 821p.

Goeldi, E.A. 1904. Album de aves amazônicas. Belém, Museu Paraense de História Natural e Etnographia, 258p.

HAYes, F.E. 2001. Identification of Least Tern Sterna antillarum and Yellow-billed Tern $S$. superciliaris, with a sight record of Yellow-billed Tern from Tobago, West Indies. Cotinga 15: 10-13.

Hays, H.; P.C. Lima; L. Monteiro; J. DiCostanzo; G. Cormons; I.C.T. Nisbet; J.E. Saliva; J.A. Spendelow; J. Burger; J. Pierce \& M. GochFELD. 1999. A nonbreeding concentration of Roseate and Common Terns in Bahia, Brazil. Journal of Field Ornithology 70 (4): 455-464.

Henriques, L.M.P. \& D.C. Oren. 1997. The avifauna of Marajó, Caviana and Mexiana islands, Amazon River Estuary, Brazil. Revista Brasileira de Biologia 57 (3): 357-382.

Hellmayr, C.E. 1929. A contribution to the ornithology of northeastern Brazil. Field Museum of Natural History Publication, Zoologial Series 12: 235-500.

Hellmayr, C.E. \& B. Conover. 1948. Catalogue of Birds of the Americas and the adjacent islands in Field Museum of Natural History. Part I, Number 2. Field Museum of Natural History Publication, Zoological Series 13: 1-434.

Johnson, D.H.; J.V. Remsen-Jr. \& C. Cicero, C. 1998. Refined colorimetry validates endangered subspecies of the Least Tern. The Condor 100 (1): 18-26.

Lima, L.M.; F. Schunck; S. Siciliano; C. J. Carlos; B. Rennó; F.P. Fonseca-Neto; C.E. Fedrizzi; C. Albano \& J. F. Moura. 2010. Distribuição, abundância e sazonalidade de Leucophaeus atricilla (Charadriiformes: Laridae) no Brasil. Revista Brasileira de Ornitologia 18 (3): 199-206.

Massey, B.W. 1976. Vocal differences between American Least Terns and the European Little Tern. The Auk 93 (4): 760773.

Massey, B.W. \& J.L. Atwood. 1978. Plumages of the Least Tern. Bird-Banding 49 (4): 360-371.

Moraes-Ornellas, V.S. 2009. Uma análise de 20 anos de produção acadêmica brasileira sobre aves marinhas. Atualidades Ornitológicas 152: 36-38.

Murphy, R.C. 1936. Oceanic birds of South America. New York, American Museum of Natural History, vol. 2, VII+602p.

NovaEs, F.C. 1974. Ornitologia do território do Amapá, I. Belém, Museu Paraense Emílio Goeldi, Publicações Avulsas \#25, 121p.

Olmos, F. 2002. Non-breeding seabirds in Brazil: A review of band recoveries. Ararajuba 10 (1): 31-42. 
Olrog, C.C. 1969. Chlidonias niger y Sterna albifrons, dos láridos nuevos para la Argentina. Neotrópica 15: 7-8.

Oren, D.C. 1991. Aves do estado do Maranhão, Brasil. Goeldiana Zoologia 9: 1-55.

Pacheco, J. F. \& C. Bauer. 1995. Adolf Schneider (1881-1946): alguns dados sobre a vida e a obra do chefe da expedição de 1939 do Museu de Ciências Naturais de Berlim que trouxe Helmut Sick para o Brasil. Atualidades Ornitológicas 65: 10-13.

PinTo, O.M.O. 1938. Catálogo das aves do Brasil e lista dos exemplares que as representam no Museu Paulista. $1^{\text {a }}$ Parte. Revista do Museu Paulista 22: 1-566.

PINTo, O.M.O. 1964. Ornitologia. Brasiliense. São Paulo, Departamento de Zoologia da Secretaria da Agricultura do Estado de São Paulo, vol. 1, 182p.

PinTo, O.M.O. 1978. Novo catálogo das aves do Brasil. Primeira parte: aves não Passeriformes e Passeriformes não Oscines, com exclusão da família Tyrannidae. São Paulo, Empresa Gráfica da Revista dos Tribunais, XVI+446p.

ReISER, O. 1905. Über die ornithologische Ausbeute während der von der kaiserlichen Akademie der Wissenschaften im Jahre 1903 nach Brasilien entsenderen Expedition. Anzeiger der Kaiserlichen Akademie der Wissenschaften in Wien, Mathematisch-Naturwissenschaftliche Klasse 42: 320-324.

ReISER, O. 1910. Liste der Vogelarten welche auf der von der Kaiserl: Akademie der Wissenschaften 1903 nach Nordostbrasilien entsendeten expedition unter leitung des hofrates Dr. F. Steindachner gesammelt wurden. Denkschriften Akademie der Wissenschaften in Wien, MathematischNaturwissenschaftliche Klasse 76: 55-100.

Remsen JR, J.V. 2001. True winter range of the Veery (Catharus fuscescens): lessons for determining winter ranges of species that winter in the tropics. The Auk 118 (4): 838-848. doi:http://dx.doi.org/10.1642/0004-8038(2001)118[0838: TWROTV]2.0.CO;2

Rocchi, A. 2011. Primer registro de gaviotín chico boreal Sternula antillarum Lesson, 1847 (Aves, Charadriiformes) para Uruguay Achará 2: 2-4.

RODRIGUES, A.A.F. 2007. Priority areas for conservation of migratory and resident waterbirds on the coast of Brazilian Amazonian. Revista Brasileira de Ornitologia 15 (2): 209-218.

Rodrigues, A.A.F.; L.R.P. Bezerra; A.S. Pereira; D.L. Carvalho \& A.T.L. Lopes. 2010. Reprodução de Sternula antillarum (Charadriiformes: Sternidae) na costa amazônica do Brasil. Revista Brasileira de Ornitologia 18 (3): 219-221.
Sanabria, J.A.F. \& G.M. Brusco. 2011. Registros relevantes de Charadriiformes em praias do litoral norte do Rio Grande do Sul, Brasil. Revista Brasileira de Ornitologia 19 (4): 529534.

SICK, H. 1985. Ornitologia brasileira: uma introdução. Brasília, Universidade de Brasília, vol. 1, XIX+481p.

SICK, H. 1997. Ornitologia brasileira. Rio de Janeiro, Nova Fronteira, 912p.

SNethlage, E. 1914. Catálogo das aves amazônicas, contendo todas as espécies descriptas e mencionadas até 1913. Boletim do Museu Paraense de História Natural e Ethnographia 8: $1-530$.

Snethlage, H. 1928a. Meine Reise durch Nordostbrasilien. II. Biologische Beobachtungen. Journal für Ornithologie 76 (3): 503-581.

Snethlage, H. 1928b. Meine Reise durch Nordostbrasilien. III. Bausteine zur Biologie der angetroffenen Arten. Journal für Ornithologie 76 (4): 668-738.

SpaAns, A.L. 1978. Status of terns along Surinam coast. BirdBanding 49 (1): 66-76.

Teixeira, D.M.; D.C. Oren \& R. Best. 1986. Notes on some Brazilian seabirds (2). Bulletin of the British Ornithologists' Club 106 (2): 74-77.

Thompson, B.C.; J.A. Jackson; J. Burger; L.A. Hill; E.M. Kirsch \& J.L. Atwood. 1997. Least Tern (Sterna antillarum). In: A. Poole \& R. GILl (Eds). The birds of North America, \#290. Washington, D.C., The Academy of Natural Sciences, The American Ornithologists' Union.

TOMCZAK, M. \& J.S. GODFReY. 2003. Regional oceanography: an introduction. New Delhi, Daya Publishing House, XI+390p, $2^{\text {nd }}$ ed.

U.S. Fish and Wildlife Service. 1985. Recovery plan for the California Least Tern, Sterna antillarum brownii. Portland, UFWS, 112p.

U.S. Fish and Wildlife Service. 1990. Recovery plan for the interior population of the Least Tern (Sterna antillarum). Bethesda, UFWS, IV+90p.

Vooren, C.M. \& L.F. Brusque. 1999. Aves do ambiente costeiro do Brasil: biodiversidade e conservação. Rio Grande, Fundação Universidade Federal de Rio Grande, 139p.

Xavier, B. \& R.L. Boss. 2011. Estação Ecológica Maracá-Jipioca, p. 28-32. In: R.M. Valente; J.M.C. Silva; F.C. Straube \& J.L.X. NasСIMENTO (Eds). Conservação de aves migratórias Neárticas no Brasil. Belém, Conservação Internacional, 400p.

Submitted: 02.VIII.2012; Accepted: 16.IX.2012.

Editorial responsibility: Diego Astúa de Moraes

ZOOLOGIA 30 (2): 135-142, April, 2013 


\section{Errata for ZOOLOGIA volume 30(2)}

Volume 30(2), page 135:

The correct version for Figure 1 is presented below:

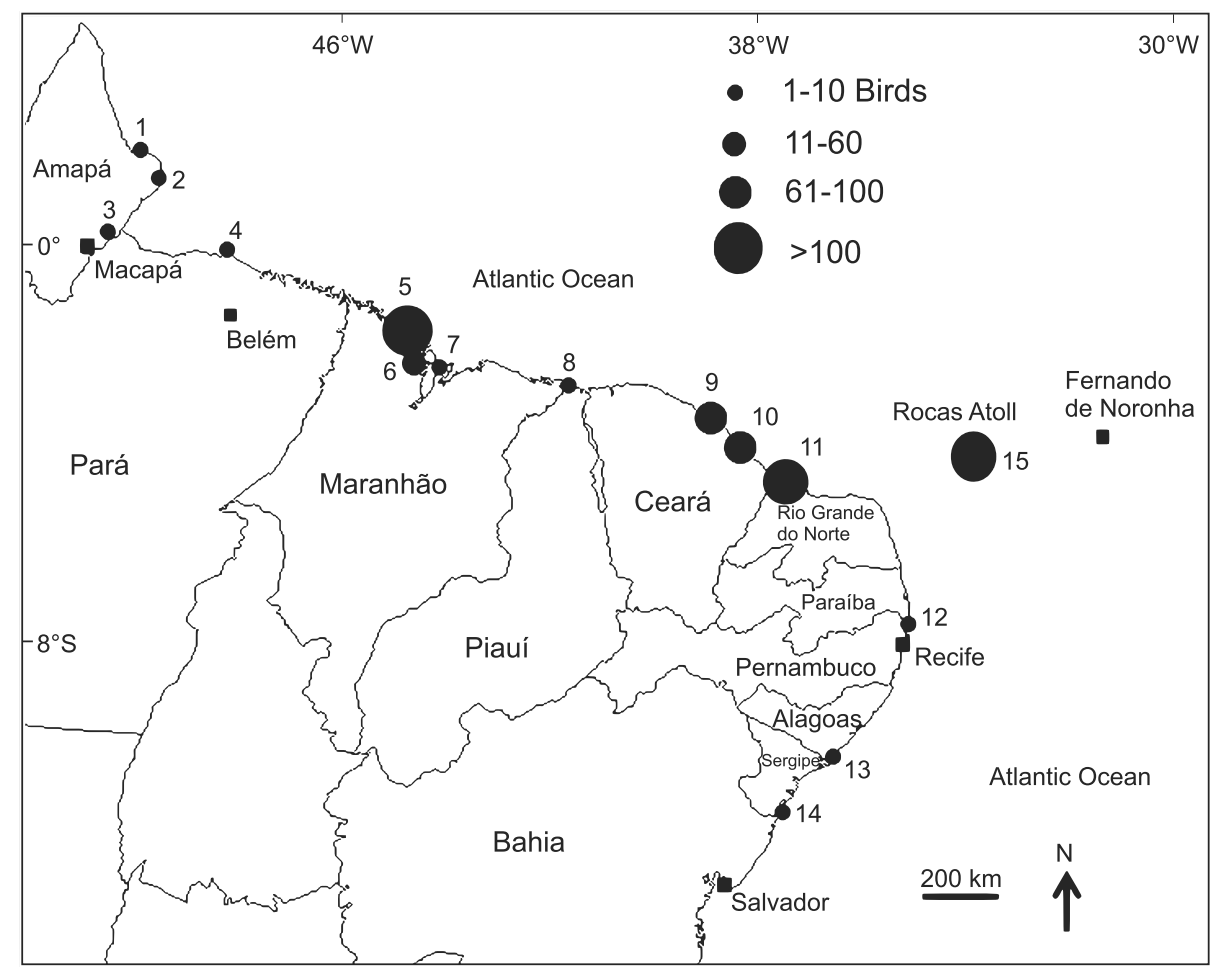

All changes are already incorporated in the online version of these articles available at http://www.scielo.br/zool 